\title{
CONSUMPTION OF DRY MATTER OBSERVED AND PREDICTED BY THE NUTRITIONAL SYSTEMS IN SENEPOL BULLS KEPT IN CONFINEMENT
}

\author{
CONSUMO DE MATÉRIA SECA OBSERVADO E PREDITO PELOS SISTEMAS \\ NUTRICIONAIS EM TOUROS SENEPOL MANTIDOS EM CONFINAMENTO
}

\begin{abstract}
Aline Maria Soares FERREIRA ${ }^{1}$; Simone Pedro da SILVA² ${ }^{2}$ Carina Ubirajara de FARIA ${ }^{2}$; Egleu Diomedes Marinho MENDES ${ }^{3}$; Ester Ferreira FELIPE ${ }^{4}$

1. Universidade Federal de Uberlândia - UFU, Faculdade de Medicina Veterinária - FAMEV, Uberlândia, MG, Brasil. alinemsferreira@hotmail.com; 2. FAMEV-UFU, Uberlândia, MG, Brasil; 3. Médico Veterinário, Cientista de dados na GrowSafe Systems Ltd; Canada; 4. Universidade Estadual Paulista "Júlio de Mesquita Filho"- Campus Jaboticabal, São Paulo, SP.
\end{abstract}

\begin{abstract}
The objective was to compare the dry matter consumption (CMS) observed, through the use of the GrowSafe ${ }^{\circledR}$ electronic system, with that predicted by the BR-Corte (2010 and 2016) and NRC (2000) nutritional systems in confined Senepol bulls. To this end, 24 Senepol Bulls were used in a completely randomized design, uncastrated with an average initial weight of $368 \mathrm{~kg}$ and 16 months of age. The evaluation of the accuracy and approximation of the CMS estimates by the nutritional systems was adjusted by the simple linear regression model and the decomposition of the mean square of the prediction error (QMEP). The mean CMS observed was $10.33 \mathrm{~kg}$.day-1, higher than the values predicted by the nutritional systems, in which the values predicted by the NRC (2000) and BR-Corte 2010 and 2016 underestimated the CMS by 29.62, 6.19 and $2.03 \%$, respectively. The verification of QMEP and its decomposition made it possible to infer the proximity of the values predicted by the BR-Corte 2010 and 2016 models and the values observed, which presented a better adjustment in relation to the NRC. Surprisingly the values predicted by the NRC, created from a database with Bos taurus animals, showed greater distance from the values predicted and observed, and it was expected greater accuracy of the NRC models for this category and animal breed. It is concluded that the BR-Corte 2016 was the most appropriate model to estimate the CMS of confined Senepol bulls.
\end{abstract}

KEYWORDS: Bos taurus. BR-Corte. Equations. Nutrition. Electronic feeding systems.

\section{INTRODUCTION}

The knowledge of the daily feed intake by the animals is essential to the zootechnical planning of productive system, in which it is possible to determine the size of the pasture area and establishment of crops for silage, as well as in the control of feed stocks, besides allowing identification and selection of animals with better feed efficiency, improving productivity and reducing production costs. (MERCADANTE; GRION, 2013).

Dry matter intake (DMI) is affected by many factors, among which we can highlight aspects related to food, animal, environment and/or management (BERCHIELLI; PIRES; OLIVEIRA, 2011). Cattle herds in Brazil are found in greater density in the tropical region with temperatures above $25{ }^{\circ} \mathrm{C}$. In fact, the environmental temperature is an important factor in regulating the intake. Fox, Sniffen and O'Conner (1988) suggested that, in temperatures ranging from 25 to $35{ }^{\circ} \mathrm{C}$, the DMI prediction was reduced by $10 \%$, and above $35^{\circ} \mathrm{C}$, it was reduced by $35 \%$.
This set of factors make this variable very difficult to estimate through mathematical models, but despite the complexity of generating empirical equations, nutritional systems such as National Research Council (NRC), Agricultural and Food Research Council (AFRC), Cornell Net Carbohydrate and Protein System (CNCPS) and BR-Corte have been working on model adjustments to estimate DMI. The most used systems in Brazil are NRC and BR-Corte, and the American system has developed equations to predict DMI using animals as database, predominantly Bos taurus species, and the Brazilian system developed models to estimate DMI in zebu and crossbred cattle. In addition, the equations proposed by BR-Corte are easier to use because they only require information on body weight, average daily gain, and in the case of equations proposed in the 2016 edition, it also includes level of dietary concentrate (VALADARES FILHO; PAULINO; MAGALHÃES, 2006; VALADARES FILHO et al.,2010; 2016). On the other hand, the models proposed by the NRC use information of net energy from the diet and required for the animal (NRC, 
2000; 2016), which demands greater efforts to obtain it.

Valadares Filho, Paulino and Magalhães (2006) reported lack of adjustment for the models proposed by the NRC in predicting dry matter consumption of beef cattle in tropical conditions. Therefore, the purpose of the present study was to compare the DMI observed with that predicted by the BR-Corte (2010 and 2016) and NRC (2000) nutritional systems in confined Senepol bulls, and to find the system that best predicts the DMI for this cattle breed and system.

\section{MATERIAL AND METHODS}

The experiment was conducted at Capim Branco Experimental Farm of the Federal University of Uberlândia (UFU), in Uberlândia MG. Twenty-four Senepol bulls, with an average initial body weight of $368 \mathrm{~kg}$ and 16 months old were used. All bulls were dewormed before the feeding trials started.

The animals remained 21 days in adaptation and 70 days in a food efficiency test with earrings and were housed in two stalls $(21 \times 20 \mathrm{~m})$, equipped with four electronic GrowSafe ${ }^{\circledR}$ feeders (Olympic
Road SW, Calgary AB, Canada) to measure their individual food consumption (DMI observed). This installation contained trough feeders, with an Eternit $^{\circledR}$ tile cover, with $4 \mathrm{~m}$ of right foot and shading width $(20 \mathrm{~m} \times 7 \mathrm{~m})$. The curralete measured $840 \mathrm{~m}^{2}$, with a central drinking fountain of 2,600 liters. Each bovine had about 90 linear centimeters of feeder space. The diets were formulated to meet nutritional needs of the animals for gains of 1 kg.day ${ }^{-1}$, according to NRC (2016).

During the experimental period, the bulls were offered their diets ad libitum for 21 days in adaptation, followed by 70 days in the data collection period. The trial lasted for a total of 90 days from February 2017 to April 2017.

The experimental diet contained $60 \%$ corn silage, $28 \%$ corn, $8 \%$ soybean meal, $1 \%$ urea and $3 \%$ mineral mix. All ingredients were mixed as total mixed ration (TMR) in Casale $^{\circledR}$ forage mixer (Vertimix model, Casale Equipamentos, São Carlos, SP, BR), for about 10 minutes. Samples of the ingredients from total diets were sampled every 14 days to determine chemical analyses, according to the methodology by Detmann et al. (2012), and the total digestible nutrient content (TDN) was estimated according to NRC (2000) (Table 1).

Table 1. Chemical composition of the diets fed to cattle in experimental trial.

\begin{tabular}{ll}
\hline Chemical Composition (\%) & \\
\hline Dry matter & 52.66 \\
Mineral matter & 3.41 \\
Crude protein & 11.20 \\
Ethereal extract & 2.52 \\
Neutral detergent fiber & 33.73 \\
Acid detergent fiber & 18.94 \\
NDICP & 1.32 \\
ADIP & 0.91 \\
Lignin & 1.85 \\
Non-fibrous carbohydrates & 45.14 \\
TDN & 71.36 \\
\hline
\end{tabular}

*NDICP $=$ Neutral detergent insoluble crude protein; ADIP = Acid Detergent Insoluble Protein; TDN= total digestible nutrients.

The temperature and air humidity were monitored twice a day at $8 \mathrm{AM}$ and $4 \mathrm{PM}$ using a thermohygrometer (AKSO, AK28 model) installed near the confinement. Rainy days and presence of mud in the animals were verified daily. During the experimental trial, the average temperature was $25.09{ }^{\circ} \mathrm{C}$, relative humidity was $64.43 \%$, with presence of light mud. This information was used in calculations of adjustment factors for dry matter intake, proposed by the NRC equations (2000).

Table 2. Minimum, maximum and average of temperature and humidity index (THI) during the trial.

\begin{tabular}{llll}
\hline & June & July & August \\
\hline MinimumTHI & 68 & 64 & 74 \\
Maximum THI & 80 & 78 & 80 \\
Average THI & 73 & 72 & 76 \\
\hline
\end{tabular}

Temperature and humidity index (THI) according to BERMAN et al. (2016). 
The DMI prediction equations used were NRC (2000), BR-Corte (2010) for crossbreed bulls with cutting and BR-Corte (2016) for crossbreed bulls through the level of dietary concentrate.

The variables measured were individual dry matter intake and the average daily gain, in which the animals were weighed fasting for 16 hours at beginning and end of experiment.

The net energy of the diet was obtained through the estimated TDN value of diets, with conversion of digestible energy into metabolizable energy, according to NRC (2016) and for obtaining the net energy of maintenance and gain, the equations proposed by Fox, Tylutki and Tedeschi (2003) were adopted.

The evaluation of the accuracy of DMI estimates by the nutritional systems was adjusted by the simple linear regression model of the observed values (dependent variable) on predicted values (independent variable) and the statistical tests were conducted under the following hypotheses: $\mathrm{H}^{0}:{ }_{\beta}{ }^{0}=$ 0 and ${ }_{\beta}{ }^{1}=1 \mathrm{X} \mathrm{H}^{1}$ : not $\mathrm{H}^{0}$.

In the case of non-rejection of the nullity hypothesis, it was concluded by similarity between predicted and observed values. The predicted values were plotted on the $\mathrm{X}$ axis, while values observed on the $\mathrm{Y}$ axis may contain natural variability, whereas the model-predicted values are deterministic with no aleatory variation (MAYER; BUTLER, 1993).

The comparative evaluation of prediction efficiency among nutritional systems was made through the evaluation and decomposition of the mean square prediction errors (MSEP), according to protocols described by Kobayashi and Salam (2000), using the Model Evaluation System program (MES) (TEDESCHI, 2017).

\section{RESULTS AND DISCUSSIONS}

The average DMI observed in Senepol bulls was $10.33 \mathrm{~kg}$ day $^{-1}$ (Table 2), a value higher than the values predicted by the nutritional systems. The NRC (2000) and BR-Corte 2010 and 2016 models underestimated DMI by 29.62, 6.19 and 2.03\%, respectively (Table 3). Similar values of DMI observed in the present study were found by Guimarães (2016), when they evaluated associations between residual feed intake (RFI) and ingesting behavior characteristics in Senepol cattle, fed with corn silage, brachiary hay, ground corn, soybean meal and mineral, with an average $\mathrm{CP}$ of 13.7 and TDN of 70.4, verified average DMI for more efficient animals (negative RFI) of $10.9 \mathrm{~kg}$ DM.day ${ }^{-}$ ${ }^{1}$ and for less efficient animals (positive RFI) of 12.3 kg DM.day ${ }^{-1}$.

Table 3. Minimum and maximum dry matter intake, observed and predicted (kg.day ${ }^{-1}$ ) by the nutritional systems NRC (2000) and BR-Corte (2010 and 2016) in Senepol bulls.

\begin{tabular}{llllllll}
\hline & & \multicolumn{7}{c}{ Predicted } \\
\cline { 3 - 7 } & & ed & Observ & N & NRC 2000 & BR Corte & BR Corte \\
\hline \multirow{2}{*}{ mum } & Mini & 7.48 & 24 & 6.61 & 8.49 & 8.89 \\
age & Aver & 10.33 & 24 & 7.27 & 9.69 & 10.12 \\
mum & Maxi & 12.56 & 24 & 9.26 & 11.99 & 13.49 \\
\hline
\end{tabular}

N: number of animals analyzed.

The average daily gain (ADG) of Senepol bulls was $1.860 \mathrm{~kg}$, being $0.860 \mathrm{~g}$ higher than expected for this experiment $\left(1 \mathrm{~kg} \cdot \mathrm{day}^{-1}\right)$. This can be explained by the genetic potential of these animals, which are also participants in tests of performance and feed efficiency. According to Guimarães (2016), when evaluating Senepol bulls, with initial weight of $321 \mathrm{~kg}$, average age of 16 months and fed with corn silage, in a bulky proportion 60:40 concentrate, found average daily gains of $1.37 \mathrm{~kg} \cdot$ day $^{-1}$. According to Valadares Filho et al. (2016), in order for the country productivity indexes to continue to increase, it is necessary to constantly update and validate the knowledge generated in research, so that the largest number of sources of variation can be known and considered in DMI prediction models. The authors also state that, in this sense, the selection of genetically superior individuals in feed efficiency becomes an urgent need to be implemented in DMI prediction models. For Berchielli, Pires and Oliveira (2011), the higher the animal production, the higher the demand for nutrients and, consequently, the dry matter intake increases. Therefore, with the advancement of technologies and genetic selection of animals, we can highlight the influence of genetic potential on 
dry matter consumption. Such information may justify the observed consumption of the bulls higher than the consumption predicted by nutritional systems (Table 3 ), contributing to discussions that there may possibly be a lack of adjustments in nutritional models for the genetic potential of animals evaluated. Therefore, it is necessary to conduct further studies so that new adjustments are can be incorporated into models.
When comparing the observed DMI with that predicted by the BR-Corte and NRC nutritional systems (Table 4), the regression analyses indicated that the slope (B) was not different from one (P > 0.01 ), and the intercept was also not different from zero $(\mathrm{P}>0.01)$, which indicates that, in fact, the models tended to be parallel to lines $\mathrm{Y}=\mathrm{X}$, concluding that there was similarity between the predicted and observed values.

Table 4. Regression analysis of dry matter consumption values, observed and predicted, by NRC (2000) and BR-Corte (2010 and 2016) systems for Senepol bulls.

\begin{tabular}{|c|c|c|c|c|c|c|c|}
\hline Systems & $\mathrm{R}^{2} \mathrm{a}$ & A & B & MSE & $\begin{array}{l}\text { Value P } \\
(\text { Ho: } a=0)\end{array}$ & $\begin{array}{l}\text { Value P (Ho: } \\
\qquad \mathrm{b}=1)\end{array}$ & $\begin{array}{c}\text { Value } \mathrm{P}^{\mathrm{I}} \\
(\mathrm{Ho}: \mathrm{a}=0 \text { and } \\
\text { Ho: } \mathrm{b}=1)\end{array}$ \\
\hline NRC 2000 & 0.057 & 6.963 & 0.463 & 1.232 & 0.026 & 0.195 & $<0.001$ \\
\hline BR-Corte 2010 & 0.064 & 6.314 & 0.415 & 1.223 & 0.067 & 0.097 & $<0.001$ \\
\hline BR-Corte 2016 & 0.066 & 7.362 & 0.293 & 1.221 & 0.01 & 0.01 & $<0.001$ \\
\hline
\end{tabular}

$\mathrm{R}^{2} \mathrm{a}=$ adjusted coefficient of determination; $\mathrm{a}=$ intercept; $\mathrm{B}=$ slope; $\mathrm{MSE}=$ mean standard error; Value $\mathrm{P}=$ probability of significance at $1 \%$; Value $\mathrm{P}^{1}=$ probability of significance at $1 \%$ of $\mathrm{a}=0$ and $\mathrm{B}=1$, simultaneously.

In general we can infer that the models presented good accuracy, but low precision. The values of $\mathrm{R}^{2}$ (Table 4 ), were able to explain from 5 to $7 \%$ of variations between the observed and predicted values. However, it is wrong to say that an $\mathrm{R}^{2}$ close to zero does not indicate a correlation between the observed and predicted values, because this relationship may be curvilinear (TEDESCHI, 2006). It is ideal for these cases to submit the data to the decomposition of the mean square errors of prediction (MSEP), according to protocols described by Kobayashi and Salam (2000).
The verification of the MSEP and its decomposition for Senepol bulls (Table 5) made it possible to infer the proximity of the values predicted by the BR-Corte 2010 and 2016 models and the values observed, which presented better adjustment in relation to the NRC, since they had lower MSEP values. Surprisingly, the values predicted by the NRC, created from a database with Bos taurus animals, showed greater distance from the values predicted and observed (MSEP $=10.59)$, and it was expected greater accuracy of NRC models for this category and animal breed.

Table 5. Analysis of mean square error of prediction (MSEP) and its decomposition for Senepol bulls.

\begin{tabular}{llll}
\hline & NRC 2000 & BR-Corte & $\begin{array}{c}\text { BR- } \\
\text { Corte 2016 }\end{array}$ \\
\hline MSEP & 10.59 & 1.68 & 1.62 \\
MSEP variance & 39.18 & 3.04 & 3.04 \\
MSEP standard deviation & 6.26 & 1.74 & 1.74 \\
MSEP coefficient of variation (\%) & 59.05 & 103.66 & 107.69 \\
MSEP square root & 3.25 & 1.29 & 1.27 \\
Mean bias & 3.06 & 0.64 & 0.2 \\
CD & 0.12 & 1.39 & 1.25 \\
MEF & -7.85 & -0.40 & -0.35 \\
CCC (rc+-SE) & 0.03 & 0.18 & 0.25 \\
Cb (bias correction) & 0.12 & 0.72 & 0.97 \\
\hline Mean deviation (\%) & Decomposition of MSEP & \\
Systematic deviation (\%) & 88.48 & 24.35 & 2.63 \\
Random errors (\%) & 0.86 & 9.11 & 28.26 \\
\hline
\end{tabular}

$\mathrm{MSEP}=$ mean square error of prediction; Mean bias $=$ average trend between the data; $\mathrm{CD}=$ coefficient of determination model; $\mathrm{MEF}=$ modeling efficiency; $\mathrm{CCC}=$ concordance correlation coefficient; $\mathrm{Cb}=$ bias correction factor. 
According to the decomposition of MSEP for Senepol bulls, the model suggested by BR-Corte 2016 showed a very low mean deviation $(2.62 \%)$, stating that the values were within a known range and the model showed a good fit, with most errors associated with random errors $(69.11 \%)$. The Mean bias (0.2), $\mathrm{CCC}(0.25)$ and $\mathrm{Cb}(0.97)$ were able to justify the BR-Corte 2016 model as the one of better precision in which the values were well uniform, simultaneously with greater precision and accuracy, and there was little deviation of the $\mathrm{Y}=\mathrm{X}$ line.

The coefficient of determination of the model indicated superior prediction of the BR-Corte 2010 and 2016 systems $(C D=1.39$ and 1.25), since according to Tedeschi (2006), the ideal is $\mathrm{CD}=1$. Therefore, from all the criteria, we conclude that for Senepol bulls the model suggested by BR-Corte 2016 is more adequate than NRC and BR-Corte 2010 models.

No publications with predictions of DMI were found by the nutritional systems in Senepol cattle. Rezende et al. (2011), when evaluating the DMI predictions of the NRC and CNCPS systems for crossbreed cattle (Holstein/Zebu), concluded that all of them were not efficient in predicting the DMI of cattle fed $80 \%$ dietary concentrate. Machado Neto et al. (2010), when evaluating the DMI of Nelore and Red North calves and comparing the values predicted by NRC (2000), CNCPS 5.0 and BR-Corte, receiving $50 \%$ concentrate in the diet, found an average DMI of 10.66 and $10.44 \mathrm{~kg} \cdot \mathrm{day}^{-1}$, respectively, and the NRC, CNCPS and BR-Corte systems underestimated the DMI, however with less differences between the observed and predicted DMI for crossbreed animals. This interpretation is similar to the results found in this study for the Senepol breed.

According to Valadares Filho, Paulino and Magalhães (2006), the NRC equations are inadequate to predict dry matter consumption of confined beef cattle when fed in tropical conditions, regardless of race group, weight gain rate and sex. Therefore, for this work, the models proposed by BR-Corte were more adequate to estimate DMI in Senepol bulls, since, even though they are classified as Bos taurus, they are animals adapted to Brazilian climatic conditions.

\section{CONCLUSION}

The model for the prediction of dry matter consumption in bovine animals proposed by the BRCorte 2016 systems were more suitable for estimating the dry matter consumption of Senepol bulls, due to their greater precision and accuracy.

RESUMO: Objetivou-se comparar o consumo de matéria seca (CMS) observado, por meio do uso do sistema eletrônico GrowSafe ${ }^{\circledR}$, com o predito pelos sistemas nutricionais BR-Corte (2010 e 2016) e NRC (2000) em touros da raça Senepol em confinamento. Para isso, foram utilizados 24 Touros da raça Senepol em delineamento inteiramente casualizado, não castrados com peso inicial médio $368 \mathrm{~kg}$ e 16 meses de idade. A avaliação da exatidão e aproximação das estimativas do CMS pelos sistemas nutricionais foi ajustada pelo modelo de regressão linear simples e decomposição do quadrado médio do erro de predição (QMEP). O CMS médio observado foi de $10,33 \mathrm{~kg}$. dia ${ }^{-1}$, valor superior aos valores preditos pelos sistemas nutricionais, no qual os valores preditos pelo NRC (2000) e BR-Corte 2010 e 2016 subestimaram o CMS em 29,62, 6,19 e 2,03\%, respectivamente. A verificação do QMEP e sua decomposição possibilitou inferir sobre a proximidade dos valores preditos pelos modelos BR-Corte 2010 e 2016 e os valores observados, os quais apresentaram melhor ajuste em relação ao NRC. Surpreendentemente os valores preditos pelo NRC, criado a partir de banco de dados com animais Bos taurus, apresentou maior distanciamento dos valores preditos e observados, sendo que era esperada maior precisão dos modelos NRC para esta categoria e raça animal. Conclui-se que o BR-Corte 2016 foi o modelo mais adequado para estimar o CMS de touros da raça Senepol em confinamento.

PALAVRAS-CHAVE: Bos taurus. BR-Corte. Equações. Nutrição. Sistemas eletrônicos de alimentação.

\section{REFERENCES}

BERCHIELLI, T. T.; PIRES, A. V.; OLIVEIRA, S. G. Nutrição de Ruminantes. $2^{a}$ Edição. Jaboticabal - SP: FUNEP - Fundação de Apoio a Pesquisa, Ensino e Extensão, 2011. ISBN: 85-87632-72-8. 
BERMAN, A. et al. A comparison of THI indices leads to a sensible heat-based heat stress index for shaded cattle that aligns temperature and humidity stress. International Journal of Biomoteorology, Ohio, v. 60, n. 10, p. 1453-1462, 2016. https://doi.org/10.1007/s00484-016-1136-9

DETMANN, E.; SOUZA, M. A.; VALADARES FILHO, S. C.; QUEIROZ, A. C.; BERCHIELLI, T. T.; SALIBA, E. O. S.; CABRAL, L. S.; PINA, D. S.; LADEIRA, M. M.; AZEVEDO, J. A. G. Métodos para Análise de Alimentos - Instituto Nacional de Ciência e Tecnologia de Ciência Animal. Visconde do Rio Branco, MG: Suprema, 2012. ISBN: 978-858-17-9020-6.

FOX, D. G.; SNIFFEN, C. J.; O'CONNER, J. D. Adjusting nutrient requirements of beef cattle for animal and environmental variations. Journal of Animal Science, v.66, p.1475-1495, 1988.

https://doi.org/10.2527/jas1988.6661475x

FOX, D. G; TYLUTKI, T. P.; TEDESCHI, L. O. Sistema de carboidratos e proteínas líquidos para avaliação da nutrição de rebanhos e excreção de nutrientes (CNCPS Versão 5.0). Juiz de Fora: Embrapa Gado de Leite, 2003. 202 p.

GUIMARÃES, A. L. Associações entre eficiência alimentar, características de comportamento ingestivo, crescimento e carcaça em bovinos Senepol. Instituto de Zootecnia: Nova Odessa, SP, 2016. Dissertação de Mestrado.

KOBAYASHI, K.; SALAM, M. U. Comparing simulated and measured values using mean squared deviation and its components. Agronomy Journal, v.92, n.2, p.345-352, 2000.

https://doi.org/10.2134/agronj2000.922345x

MACHADO NETO, O. R.; LADEIRA, M. M.; GONÇALVES, T. M.; LOPES, L.S.; OLIVEIRA, D. M.; BASSI, M. S. Feed intake and prediction assessments using the NRC, CNCPS and BR-CORTE systems in Nellore and Red Norte steers finished in feedlot. Revista Brasileira de Zootecnia, v. 39, n.2, p.394-401. 2010. http://dx.doi.org/10.1590/S1516-35982010000200024

MAYER, D. G.; D. G. BUTLER. Statistical validation. Ecological Modelling. v. 68, p. 21-32. 1993. https://doi.org/10.1016/0304-3800(93)90105-2

MERCADANTE, M. E. Z.; GRION, A. L. Perspectivas de inclusão da eficiência alimentar em programas de melhoramento genético de bovinos de corte. In: X SIMPÓSIO BRASILEIRO DE MELHORAMENTO ANIMAL, 2013, Uberaba, MG. Anais... Uberaba: SBMA, 2013. p.1-14.

NATIONAL RESEARCH COUNCIL - NRC. Nutrient requirements of beef cattle. 7.ed. rev. Washington: D.C., 2000. 234 p. https://doi.org/10.17226/9791.

NATIONAL RESEARCH COUNCIL - NRC. Nutrient requirements of beef cattle. Washington: Eighth Revised Edition., 2016. 494 p. https://doi.org/10.17226/19014.

REZENDE, P. L. P.; NETO, M. D. F.; RESTLE, J.; FERNANDES, J. J. R.; PÁDUA, J. T.; QUEIROZ, G. A. Validação de modelos matemáticos para predição de consumo voluntário e ganho em peso de bovinos. Archivos de Zootecnia, v. 60, n. 01, p. 2-10, 2011. http://dx.doi.org/10.4321/S0004-05922011000400009

TEDESCHI, L. O. Assessment of the adequacy of mathematical models. Agricultural Systems, v. 89, n. 02/03, p. 225-247. 2006. https://doi.org/10.1016/j.agsy.2005.11.004

TEDESCHI, L. O. Model evaluation System, versão 3.1.17. 2017. Disponível em $<$ http://nutritionmodels.com/mes.html $>$. Acesso em: 5 out. 2018.

VALADARES FILHO, S. C.; PAULINO, P. V. R.; MAGALHÃES, K. A. Exigências nutricionais de zebuínos e tabelas de composição de alimentos BR-Corte. Viçosa - MG: UFV. 2006. 142 p. 
VALADARES FILHO, S. C.; MARCONDES, M. I.; CHIZZOTTI, M. L.; PAULINO, P. V. R. Exigências nutricionais de zebuínos puros e cruzados BR-Corte. 2.ed. Viçosa - MG: UFV, DZO, 2010. 193 p. ISBN: 978-85-906041-4-3.

VALADARES FILHO, S. C., COSTA E SILVA, L. F., LOPES, S. A. et al. BR-CORTE 3.0. Cálculo de exigências nutricionais, formulação de dietas e predição de desempenho de zebuínos puros e cruzados. 2016. ISBN: 978-85-8179-110-4. 